\title{
Cutaneous T-Cell Lymphoma: Trends in Radiation Doses and Patterns of Care 2004-2015
}

\author{
JOSEPH A. MICCIO ${ }^{1}$, LYNN D. WILSON ${ }^{1}$, BENJAMIN H. KANN ${ }^{1}$, VIKRAM JAIRAM ${ }^{1}$, \\ JASON BECKTA ${ }^{1}$, FRANCINE M. FOSS $^{2,3}$ and DEBRA N. YEBOA ${ }^{4}$ \\ ${ }^{1}$ Department of Therapeutic Radiology, Yale School of Medicine, New Haven, CT, U.S.A.; \\ Departments of ${ }^{2}$ Medicine and of ${ }^{3}$ Dermatology, Yale School of Medicine, New Haven, CT, U.S.A.; \\ ${ }^{4}$ Department of Radiation Oncology, MD Anderson Cancer Center, Houston, TX, U.S.A.
}

\begin{abstract}
Background and Aim: Radiotherapy is an effective treatment for cutaneous T-cell lymphoma (CTCL). Since 2009, studies have advocated for low-dose radiotherapy $(<30 \mathrm{~Gy})$ given it results in similar response rates and less toxicity compared to higher doses ( $\geq 30 \mathrm{~Gy}$ ). We aimed to see if low-dose radiotherapy has been adopted on a national scale in the USA. Materials and Methods: A total of 11,292 adult patients with CTCL were identified in the National Cancer Database. Logistic regression models were created to evaluate predictors for use of low-dose radiotherapy. Results: A minority of patients received lowdose radiotherapy (22.4\%). The annual percentage of patients receiving low-dose radiotherapy increased from $17.2 \%$ in 2009 to $38.4 \%$ in 2015. High-volume facilities were associated with use of low-dose radiotherapy (5th quintile vs. bottom two quintiles, odds $\operatorname{ratio}(O R)=1.76,95 \%$ confidence interval $(\mathrm{CI})=1.22-2.54, p=0.003)$. Conclusion: Although the radiotherapy dose administered is decreasing, most patients with CTCL are still receiving doses that may be higher than needed to palliate their disease effectively.
\end{abstract}

Cutaneous T-cell lymphoma (CTCL) is a rare neoplasm characterized by a clonal expansion of neoplastic T-cells that are localized to the skin $(25,30)$. Treatment for CTCL varies depending on disease stage and clinical responsiveness. For early-stage disease, treatments typically include topical agents (corticosteroids, nitrogen mustard, retinoids, or imiquimod) (3, $9,15,31)$, psoralen plus ultraviolet A photochemotherapy

This article is freely accessible online.

Correspondence to: Joseph A. Miccio, Smilow Cancer Hospital lower level, Department of Therapeutic Radiology, 35 Park St., New Haven, CT 06511, U.S.A. E-mail: Joseph.Miccio@yale.edu

Key Words: Radiotherapy, cutaneous T-cell lymphoma, patterns of care. phototherapy (23), ultraviolet B phototherapy (7), and localized radiation therapy (RT) for symptomatic lesions $(22,27,28)$. For more advanced or refractory disease, additional treatment options include systemic therapies (retinoids, methotrexate, histone deacetylase inhibitors, antibodies to cluster of differentiation (CD) 30, antibodies to CD52 or interferon) (4, $5,12,16,32)$ and total skin electron beam therapy (TSEBT) $(2,6,8,10,14,27,28)$.

TSEBT is one of the most effective modalities for obtaining partial or complete responses for skin lesions in CTCL (2). Treatment is delivered with the patient in several positions at an extended distance from the source by using external-beam electron RT targeted to deliver superficial doses to the skin. Historically, TSEBT was administered to total doses of $\geq 30$ Gy in 1.5- to 2-Gy fractions $(2,13,19,21,24)$, a regimen that was highly effective but was also associated with significant morbidity. Since 2011, several studies have been published advocating that low-dose TSEBT ( $<30 \mathrm{~Gy}$ ) be used for CTCL, given the similarities in overall response rates, the lesser toxicity, and the shorter treatment times compared with higher doses ( $\geq 30$ Gy) RT $(2,6,8,10,14,17)$. Use of low-dose TSEBT also makes re-irradiating recurrent skin disease more feasible because it minimizes the cumulative skin dose. This is particularly important because most patients treated with RT experience recurrence (2). The current National Comprehensive Cancer Network guidelines recommend a dose range of 12-36 Gy, but also emphasize the advantages of using lower doses, including fewer complications and the ability to re-treat progressive disease (11). The use of low-dose localized RT in the treatment of CTCL has also been studied, starting in 2009, with regimens of $2 \times 4$ Gy fractions (20) and $1 \times 7-8$ Gy (29) leading to complete response rates of $92 \%$ and $94 \%$, respectively.

Given the recent interest in using low-dose RT for CTCL [2009 for localized RT (20) and 2011 for TSEBT (8)], we sought to evaluate RT usage as part of the patterns of care for CTCL on a national scale. To do so, the National Cancer Data Base (NCDB) was retrospectively evaluated to identify 


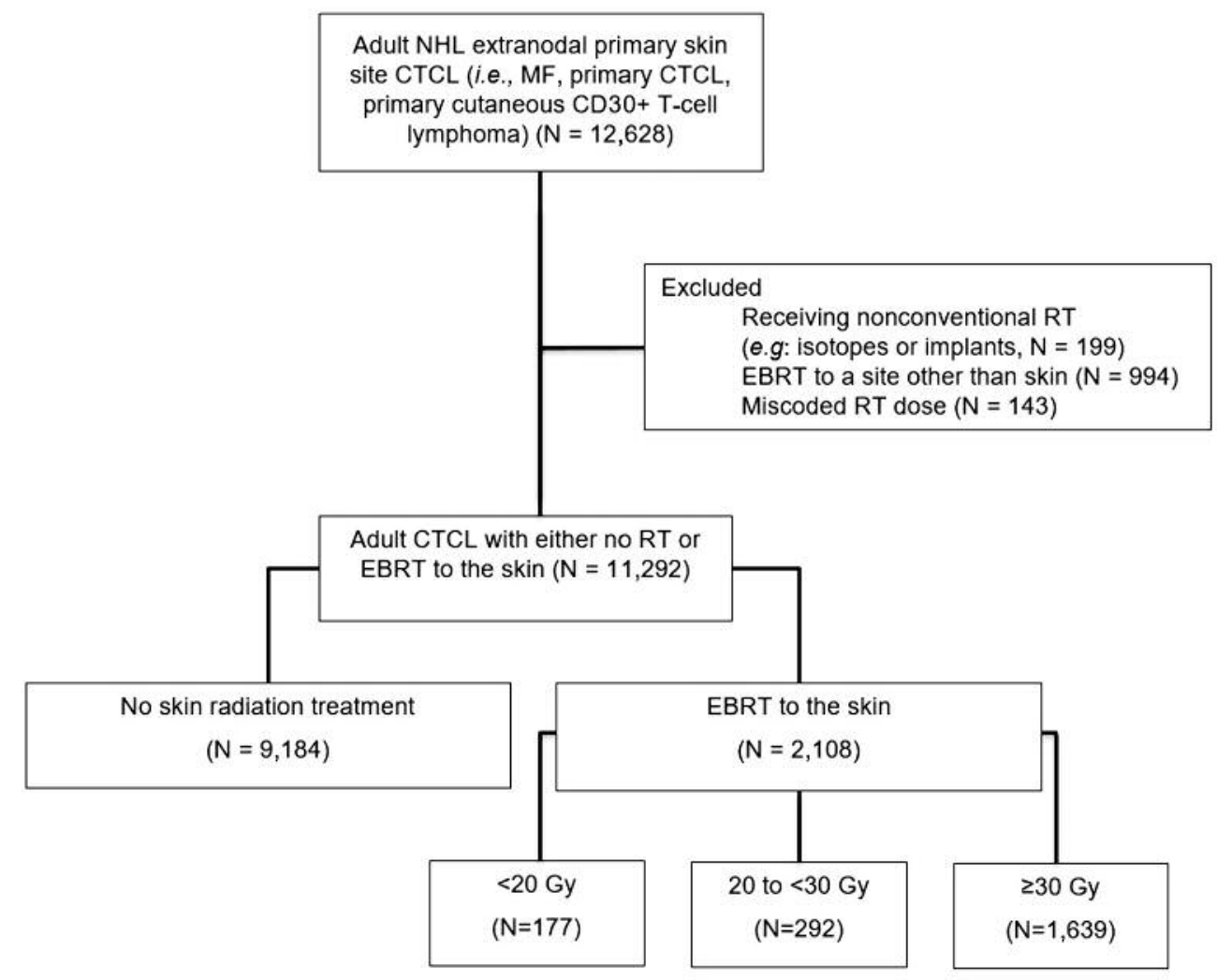

Figure 1. Process for selecting patients from the National Cancer Data Base for this analysis. NHL, Non-Hodgkin lymphoma; CTCL, cutaneous T-cell lymphoma; $M F$, mycosis fungoides; RT, radiation therapy; EBRT, external-beam radiation therapy.

trends in RT usage and dose for CTCL. Demographic factors associated with the relative decrease in use of RT were also examined. Finally, factors associated with the administration of lower-dose as opposed to higher dose RT were analyzed.

\section{Materials and Methods}

The NCDB is a joint project of the Commission on Cancer $(\mathrm{CoC})$ of the American College of Surgeons and the American Cancer Society, which consists of de-identified information regarding patient demographics, tumor characteristics, first-course treatment for the corresponding diagnosis, and survival for approximately $70 \%$ of the US population (1). All pertinent cases are reported regularly from $\mathrm{CoC}$-accredited centers and compiled into a unified dataset, which is then validated. The data used in the study were derived from a de-identified NCDB file (2004-2015). The American College of Surgeons and the $\mathrm{CoC}$ have not verified and are not responsible for the analytic or statistical methodology employed, nor the conclusions drawn from these data by the investigators. As all patient information in the NCDB database is de-identified, this study was exempt from Institutional Review Board evaluation.

A total of 12,628 adult patients with CTCL in the NCDB diagnosed from 2004 through 2015 were identified using the histology codes from the international Classification of Disease for Oncology, Third Edition (ICD-O-3). The codes used in this study included primary CTCL (\#9700), mycosis fungoides (\#9709), or CD30+ T-cell lymphoma (\#9718) with the primary site being skin. Patients receiving unconventional forms of RT such as radiosurgery, isotopes, or implants $(\mathrm{n}=119)$ were excluded. Patients receiving RT to areas other than skin $(n=994)$ and those with mis-recorded RT doses $(n=143)$ were also excluded. The final cohort consisted of 11,292 patients, including 2,108 who received RT as initial therapy and 9,184 who did not (Figure 1).

Chi-square tests were used to assess differences in the proportions of patients who received RT for CTCL between different years. Univariate and multivariable logistic regression models were used to evaluate the likelihood of receipt (versus no receipt) of RT, and to evaluate the likelihood of receipt of RT doses $<30$ Gy versus $\geq 30$ Gy. Covariates included age, sex, race, comorbidity (Charlson-Deyo comorbidity score), sociodemographic factors, facility type, year of diagnosis, disease stage, and therapy received. For the low-dose versus high-dose $\mathrm{RT}$ analysis, a facility volume variable was also added as we theorized that facilities with high treatment volumes would be more likely to offer low-dose RT. The facility volume was defined as the average number of patients treated annually at each of the facilities in the NCDB that treated at least one patients with CTCL with RT at diagnosis from 2004 through 2015. Facilities were then grouped together by quintiles of average number of patients treated per year. Analyses were performed with STATA (version 13; STATA Corp., College Station, TX, USA). and $p$-values of 0.05 or less were considered to indicate statistically significant differences. 
Table I. Patient characteristics.

\begin{tabular}{|c|c|c|c|}
\hline Characteristic & $\begin{array}{c}\text { RT not given, } \\
\mathrm{n}(\%)\end{array}$ & $\begin{array}{l}\text { RT given, } \\
\text { n ( } \%)\end{array}$ & $p$-Value \\
\hline Total & 9,184 & 2,108 & \\
\hline \multicolumn{4}{|l|}{ Age, years } \\
\hline $18-39$ & $1,212(3.2)$ & $169(8.0)$ & \multirow[t]{3}{*}{$<0.001$} \\
\hline $40-59$ & 3,162 (34.4) & $691(32.8)$ & \\
\hline$\geq 60$ & $4,810(52.4)$ & $1,248(59.2)$ & \\
\hline \multicolumn{4}{|l|}{ Gender } \\
\hline Male & $5,126(55.8)$ & $1,306(62.0)$ & \multirow[t]{2}{*}{$<0.001$} \\
\hline Female & $4,058(44.2)$ & $802(38.0)$ & \\
\hline \multicolumn{4}{|l|}{ Race } \\
\hline White & $6,951(75.7)$ & $1,816(86.2)$ & \multirow[t]{4}{*}{$<0.001$} \\
\hline Black & $1,634(18.0)$ & $203(9.4)$ & \\
\hline Asian & $252(2.5)$ & $37(1.6)$ & \\
\hline Unknown & $347(3.8)$ & $52(2.8)$ & \\
\hline \multicolumn{4}{|l|}{ Comorbidity score } \\
\hline 0 & $8,178(89.8)$ & $1,871(89.3)$ & \multirow[t]{2}{*}{0.485} \\
\hline$\geq 1$ & $931(10.2)$ & $225(10.7)$ & \\
\hline \multicolumn{4}{|l|}{ Median Income } \\
\hline$<\$ 48,000$ & $3,407(37.1)$ & $679(32.2)$ & \multirow[t]{3}{*}{$<0.001$} \\
\hline$\geq \$ 48,000$ & $5,680(62.0)$ & $1,406(66.7)$ & \\
\hline Unknown & $97(1.1)$ & $34(1.1)$ & \\
\hline \multicolumn{4}{|l|}{ Insurance } \\
\hline Uninsured & $302(3.3)$ & $44(2.1)$ & \multirow[t]{4}{*}{$<0.001$} \\
\hline Government & $3,964(43.2)$ & $1,005(47.7)$ & \\
\hline Private & $4,555(49.5)$ & $1,013(48.0)$ & \\
\hline Unknown & $363(4.0)$ & $46(2.2)$ & \\
\hline \multicolumn{4}{|l|}{ Facility type } \\
\hline Non-academic & $2,041(22.2)$ & $975(46.3)$ & \multirow[t]{3}{*}{$<0.001$} \\
\hline Academic or research center & $5,931(64.6)$ & $964(45.7)$ & \\
\hline Unknown & $1,212(13.2)$ & $169(8.0)$ & \\
\hline \multicolumn{4}{|l|}{ Facility volume* } \\
\hline Bottom two quintiles ${ }^{a}$ & $777(8.5)$ & $482(22.9)$ & \multirow[t]{4}{*}{$<0.001$} \\
\hline 3rd quintile ${ }^{b}$ & $268(2.9)$ & $212(10.1)$ & \\
\hline 4th quintilec & $986(10.7)$ & $451(21.4)$ & \\
\hline 5th quintiled & $7,153(77.9)$ & $963(45.7)$ & \\
\hline \multicolumn{4}{|l|}{ Disease stage } \\
\hline I & $6,022(65.6)$ & $1,389(65.9)$ & \multirow[t]{5}{*}{$<0.001$} \\
\hline II & $644(7.0)$ & $282(13.4)$ & \\
\hline III & $490(5.3)$ & $61(2.9)$ & \\
\hline IV & $766(8.3)$ & $125(5.9)$ & \\
\hline Unknown & $1,262(13.7)$ & $251(11.9)$ & \\
\hline \multicolumn{4}{|l|}{ Chemotherapy } \\
\hline No & $5,563(60.6)$ & $1,526(72.4)$ & \multirow[t]{3}{*}{$<0.001$} \\
\hline Yes & $2,657(29.0)$ & $367(17.4)$ & \\
\hline Unknown & $964(10.5)$ & $215(10.2)$ & \\
\hline \multicolumn{4}{|l|}{ RT dose, Gy } \\
\hline 0 & $9,184(100)$ & $0(0)$ & \multirow[t]{4}{*}{$<0.001$} \\
\hline$<20$ & & $177(8.4)$ & \\
\hline $20-<30$ & & $292(13.9)$ & \\
\hline$\geq 30$ & & $1,639(77.8)$ & \\
\hline
\end{tabular}

RT, Radiation therapy. *Patients per year: ${ }^{\mathrm{a}}<1,{ }^{\mathrm{b}} 1-1.25,{ }^{\mathrm{c}} 1.25-2,{ }^{\mathrm{d}}>2$.

\section{Results}

Patient characteristics are detailed in Table I. The cohorts were unbalanced with respect to all variables except for
Table II. Annual utilization of radiation therapy for the treatment of cutaneous T-Cell lymphoma.

\begin{tabular}{lcccc}
\hline $\begin{array}{l}\text { Year of } \\
\text { diagnosis }\end{array}$ & $\begin{array}{c}\text { Patients } \\
\text { not } \\
\text { given } \\
\text { RT, n }\end{array}$ & $\begin{array}{c}\text { Percentage } \\
\text { of patients } \\
\text { treated } \\
\text { annually }\end{array}$ & $\begin{array}{c}\text { Patients } \\
\text { given RT } \\
(<20 / 20-<30 / \\
\geq 30 \mathrm{~Gy}), \mathrm{n}\end{array}$ & $\begin{array}{c}\text { Percentage } \\
\text { of patients } \\
\text { treated } \\
\text { annually }\end{array}$ \\
\hline & & & & \\
2004 & 549 & 78.2 & $153(12 / 22 / 119)$ & 21.8 \\
2005 & 634 & 76.3 & $197(9 / 21 / 167)$ & 23.7 \\
2006 & 631 & 77.7 & $181(9 / 19 / 153)$ & 22.3 \\
2007 & 668 & 82.3 & $144(8 / 17 / 119)$ & 17.7 \\
2008 & 695 & 79.3 & $181(9 / 15 / 157)$ & 20.7 \\
2009 & 870 & 81.5 & $198(12 / 22 / 164)$ & 18.5 \\
2010 & 774 & 78.8 & $208(12 / 26 / 170)$ & 21.2 \\
2011 & 758 & 80.3 & $186(10 / 39 / 137)$ & 19.7 \\
2012 & 854 & 84.9 & $152(12 / 18 / 122)$ & 15.1 \\
2013 & 895 & 85.1 & $157(19 / 27 / 111)$ & 14.9 \\
2014 & 943 & 85.4 & $161(27 / 31 / 103)$ & 14.6 \\
2015 & 913 & 82.8 & $190(38 / 35 / 117)$ & 17.2 \\
\hline
\end{tabular}

comorbidity score as follows. The RT cohort had higher proportions of older patients, male patients, and wealthier patients relative to the no-RT cohort. The no-RT cohort had higher proportions of patients seen at an academic center and patients treated at facilities with the highest-volume quintile. Most patients given RT $(77.8 \%)$ received doses of $\geq 30 \mathrm{~Gy}$; $13.9 \%$ received doses of $20-30 \mathrm{~Gy}$, and only $8.4 \%$ received doses <20 Gy. Table II and Figure 2 indicate RT doses administered by year.

The percentage of patients receiving RT as initial therapy decreased each year, from $21.8 \%$ in 2004 to $17.2 \%$ in 2015 . From 2011 through 2015, the percentage of patients treated with RT who received $<20$ Gy increased from $5.4 \%$ to $20.0 \%$, and the percentage of patients treated with RT who received $\geq 30$ Gy decreased from $73.7 \%$ to $61.6 \%$. Multivariable linear regression to evaluate variables associated with use of RT indicated that comorbidity score and type of insurance were not associated with receipt (versus no receipt) of RT (Table III). Unknown facility type was excluded from the multivariable logistic regression model due to co-linearity. In terms of trends over time, when year of diagnosis was analyzed as a continuous variable, the year of diagnosis was associated with lower use of RT [odds ratio (OR) $=0.95,95 \%$ confidence interval $(\mathrm{CI})=0.94-0.96, p<0.001)$. Other variables significantly associated with lower use of RT on multivariate analysis included being Black (versus White: $\mathrm{OR}=0.56,95 \%$ $\mathrm{CI}=0.47-0.66, p<0.001$ ), Asian (versus white: $\mathrm{OR}=0.65,95 \%$ $\mathrm{CI}=0.45-0.93, p=0.018$ ), female (versus male: $\mathrm{OR}=0.81,95 \%$ $\mathrm{CI}=0.73-0.90, p<0.001)$, treated at an academic or research center (versus nonacademic center: $\mathrm{OR}=0.34,95 \% \mathrm{CI}=0.31$ $0.38, p<0.001$ ), and receiving chemotherapy (versus no chemotherapy: $\mathrm{OR}=0.47,95 \% \mathrm{CI}=0.41-0.54, p<0.001)$. 


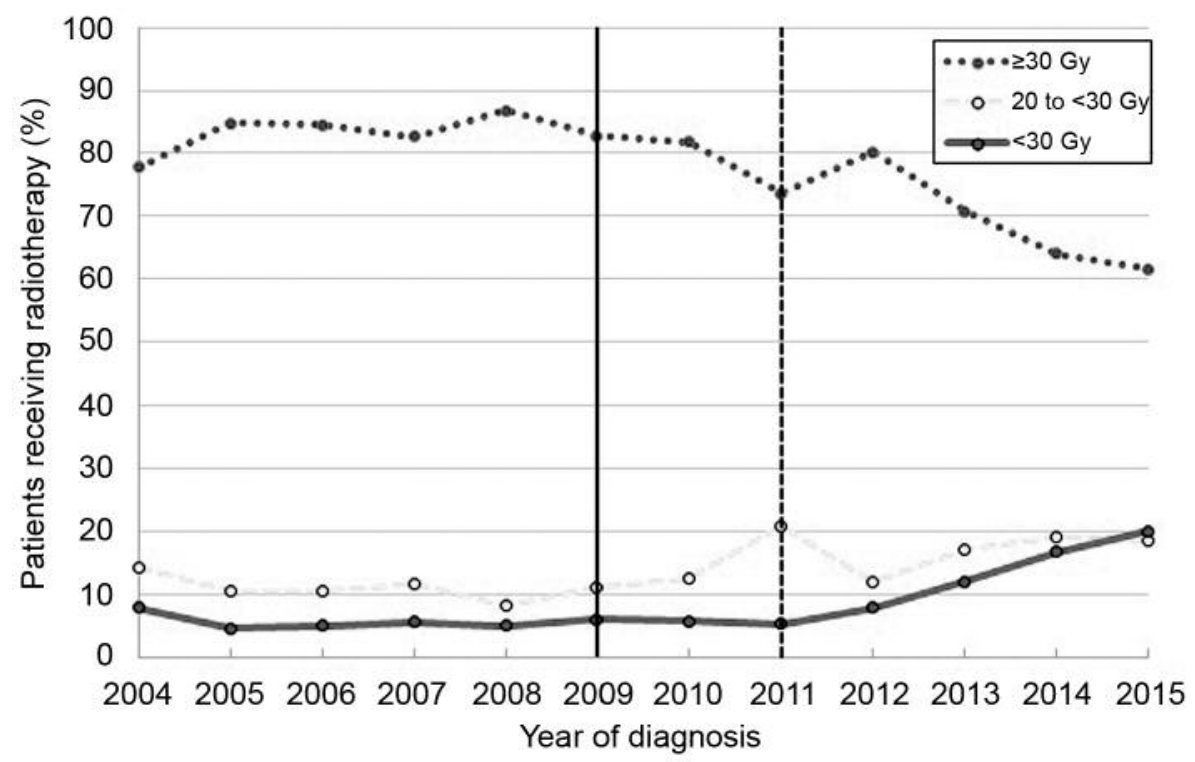

Figure 2. Yearly percentage of patients with cutaneous T-cell lymphoma receiving radiotherapy (RT) as initial therapy as a function of year of diagnosis and according to radiation dose. The solid vertical line indicates the date of the first report advocating for low-dose local RT (28) and the dashed vertical line indicates the date of the first report advocating low-dose total skin electron beam therapy (19).

Findings from multivariable logistic regression evaluating predictors of receipt of low-dose versus high-dose RT are shown in Table IV. The facility volume variable included in this analysis was derived as follows. In all, $643 \mathrm{NCDB}$-coding facilities treated at least one patient with CTCL with RT from 2004 through 2015. Based on the average number of patients treated with RT annually, the highest (5th) quintile of facility volume was determined to be more than two patients annually. In terms of year of diagnosis, patients with CTCL were more likely to receive low-dose $\mathrm{RT}$ in more recent years $(\mathrm{OR}=1.12$, 95\% CI=1.08-1.16, $p<0.001$ ) (Table IV). Treatment at a highvolume facility was also associated with receipt of low-dose RT (5th quintile $v s$. bottom two quintiles, odds ratio $(\mathrm{OR})=1.76$, $95 \%$ confidence interval $(\mathrm{CI})=1.22-2.54, p=0.003)$. Academic facilities seemed to offer low-dose RT more often than did nonacademic centers $(\mathrm{OR}=1.26,95 \% \mathrm{CI}=0.93-1.72)$, but this apparent difference was not statistically significant $(p=0.140)$.

\section{Discussion}

Our key findings from this analysis are as follows: The use of RT as the initial treatment of CTCL is decreasing, as is the dose of RT used in the treatment of CTCL; high-volume facilities are more likely to offer low-dose RT to patients with CTCL; and even though a higher proportion of patients received doses $<30 \mathrm{~Gy}$ in recent years, most patients still receive doses $\geq 30$ Gy.

Before 2011, all the published studies of TSEBT for CTCL reported outcomes after doses of an average of $30 \mathrm{~Gy}$ or more (2). Although disease severity varied in the patients in these studies, overall response rates generally exceeded $95 \%$, and complete response rates ranged from $47 \%$ for $\mathrm{T} 3$ disease to $97 \%$ for $\mathrm{T} 1$ disease $(19,24)$. The 2011 study by Harrison et al. was the first modern study to show that treating mycosis fungoides with TSEBT doses from 10 to $<30$ Gy could lead to overall response rates of $95 \%$ or more. They further found that overall and complete response rates were similar between patients receiving 20 to $<30$ Gy and 10 to $20 \mathrm{~Gy}$ ( $97 \%$ to $98 \%$ overall response, $34 \%$ to $35 \%$ complete response). However, these rates were generally lower than those in previous reports of high-dose TSEBT. For example, Harrison's group reported a response rate of $35 \%$ for patients with T3 disease given 10-20 Gy (8) as compared with $47 \%$ for patients with $\mathrm{T} 3$ disease given 30 40 Gy in a study by Navi et al. (19). Nevertheless, because high-dose TSEBT is seldom curative, Harrison and colleagues noted that treatment with $<30$ Gy TSEBT is advantageous given the adequate overall response rate $(>95 \%)$, abbreviated treatment times, and feasibility of retreatment with no significant differences in overall or progression-free survival (8). Lower doses are also associated with fewer grade 3 toxic effects than are higher doses, as well as less permanent alopecia, less fingernail loss, and no anhidrosis (10).

The first report of low-dose localized RT for CTCL was by Neelis et al. in 2009 (20). They analyzed 65 lesions treated with a regimen of $2 \times 4$ Gy fractions and showed a complete response rate of $92 \%$. In their median follow-up time of 9.6 
Table III. Results of multivariable linear regression evaluating radiotherapy for cutaneous T-cell lymphoma.

\begin{tabular}{|c|c|c|c|}
\hline Variable & $\begin{array}{l}\text { Odds } \\
\text { ratio }\end{array}$ & $\begin{array}{l}95 \% \text { Confidence } \\
\text { interval }\end{array}$ & $p$-Value \\
\hline \multicolumn{4}{|l|}{ Age, years } \\
\hline $18-39$ & 1.00 & & \\
\hline $40-59$ & 3.18 & $2.61-3.88$ & $<0.001$ \\
\hline$\geq 60$ & 3.25 & $2.66-3.98$ & $<0.001$ \\
\hline \multicolumn{4}{|l|}{ Gender } \\
\hline Male & 1.00 & & \\
\hline Female & 0.81 & $0.73-0.90$ & $<0.001$ \\
\hline \multicolumn{4}{|l|}{ Race } \\
\hline White & 1.00 & & \\
\hline Black & 0.56 & $0.47-0.66$ & $<0.001$ \\
\hline Asian & 0.65 & $0.45-0.93$ & 0.018 \\
\hline Unknown & 0.67 & $0.49-0.91$ & 0.011 \\
\hline \multicolumn{4}{|l|}{ Comorbidity score } \\
\hline 0 & 1.00 & & \\
\hline$\geq 1$ & 0.91 & $0.78-1.08$ & 0.285 \\
\hline \multicolumn{4}{|l|}{ Income } \\
\hline$<\$ 48,000$ & 1.00 & & \\
\hline$\geq \$ 48,000$ & 1.20 & $1.08-1.34$ & 0.001 \\
\hline Unknown & 1.02 & $0.62-1.66$ & 0.946 \\
\hline \multicolumn{4}{|l|}{ Insurance } \\
\hline Uninsured & 1.00 & & \\
\hline Government & 1.21 & $0.87-1.70$ & 0.264 \\
\hline Private & 1.23 & $0.87-1.74$ & 0.243 \\
\hline Unknown & 0.64 & $0.40-1.01$ & 0.054 \\
\hline \multicolumn{4}{|l|}{ Facility type } \\
\hline Non-academic center & 1.00 & & \\
\hline Academic or research center & 0.34 & $0.31-0.38$ & $<0.001$ \\
\hline \multicolumn{4}{|l|}{ Year of diagnosis } \\
\hline Continuous & 0.95 & $0.94-0.96$ & $<0.001$ \\
\hline \multicolumn{4}{|l|}{ Disease stage } \\
\hline I & 1.00 & & \\
\hline II & 2.41 & $2.04-2.84$ & $<0.001$ \\
\hline III & 0.67 & $0.51-0.89$ & 0.006 \\
\hline IV & 0.83 & $0.67-1.03$ & 0.094 \\
\hline Unknown & 0.78 & $0.67-0.91$ & 0.002 \\
\hline \multicolumn{4}{|l|}{ Chemotherapy } \\
\hline No & 1.00 & & \\
\hline Yes & 0.47 & $0.41-0.52$ & $<0.001$ \\
\hline Unknown & 0.80 & $0.68-0.95$ & 0.009 \\
\hline
\end{tabular}

months, only three lesions with complete response required retreatment. Another study conducted more recently evaluating lower dose localized RT in CTCL yielded similar results with doses of 7-8 Gy in a single fraction (29). These studies have led to the most recent International Lymphoma Radiation Oncology Group guidelines for skin lymphoma to recommend considering doses of 8 Gy in 1-2 fractions for localized RT for patients with CTCL without large tumors or large-cell transformation. The guidelines in general encourage the use of localized RT doses of 20-24 Gy given that local recurrence is rarely above this dose range. In fact, the only subset of
Table IV. Results of multivariable linear regression evaluating receipt of low-dose radiotherapy ( $<30 \mathrm{~Gy})$ versus high-dose radiotherapy for cutaneous T-cell lymphoma.

\begin{tabular}{|c|c|c|c|}
\hline Variable & $\begin{array}{l}\text { Odds } \\
\text { ratio }\end{array}$ & $\begin{array}{c}95 \% \text { Confidence } \\
\text { interval }\end{array}$ & $p$-Value \\
\hline \multicolumn{4}{|l|}{ Age, years } \\
\hline $18-39$ & 1.00 & & \\
\hline $40-59$ & 0.68 & $0.43-1.08$ & 0.100 \\
\hline$\geq 60$ & 0.69 & $0.43-1.10$ & 0.115 \\
\hline \multicolumn{4}{|l|}{ Gender } \\
\hline Female & 1.00 & & \\
\hline MaIe & 1.00 & $0.80-1.26$ & 0.972 \\
\hline White & 1.00 & & \\
\hline \multicolumn{4}{|l|}{ Race } \\
\hline Black & 0.90 & $0.63-1.30$ & 0.590 \\
\hline Asian & 0.59 & $0.23-1.48$ & 0.259 \\
\hline Unknown & 0.73 & $0.36-1.50$ & 0.396 \\
\hline \multicolumn{4}{|l|}{ Comorbidity score } \\
\hline 0 & 1.00 & & \\
\hline$\geq 1$ & 1.14 & $0.81-1.61$ & 0.450 \\
\hline \multicolumn{4}{|l|}{ Income } \\
\hline$<\$ 48,000$ & 1.00 & & \\
\hline$\geq \$ 48,000$ & 0.95 & $0.75-1.20$ & 0.654 \\
\hline Unknown & 0.84 & $0.27-2.57$ & 0.754 \\
\hline \multicolumn{4}{|l|}{ Insurance } \\
\hline Uninsured & 1.00 & & \\
\hline Government & 1.20 & $0.55-2.62$ & 0.647 \\
\hline Private & 1.29 & $0.58-2.88$ & 0.529 \\
\hline Unknown & 2.80 & $1.02-7.68$ & 0.045 \\
\hline \multicolumn{4}{|l|}{ Facility type } \\
\hline Non-academic center & 1.00 & & \\
\hline Academic or research center & 1.26 & $0.93-1.72$ & 0.140 \\
\hline \multicolumn{4}{|l|}{ Year of diagnosis } \\
\hline Continuous & 1.12 & $1.08-1.16$ & $<0.001$ \\
\hline \multicolumn{4}{|l|}{ Disease stage } \\
\hline $\mathrm{I}$ & 1.00 & & \\
\hline II & 1.91 & $1.41-2.59$ & $<0.001$ \\
\hline III & 2.39 & $1.35-4.21$ & 0.003 \\
\hline IV & 2.63 & $1.73-4.01$ & $<0.001$ \\
\hline Unknown & 1.73 & $1.24-2.42$ & 0.001 \\
\hline \multicolumn{4}{|l|}{ Chemotherapy } \\
\hline No & 1.00 & & \\
\hline Yes & 1.42 & $1.07-1.87$ & 0.014 \\
\hline Unknown & 0.79 & $0.54-1.16$ & 0.224 \\
\hline \multicolumn{4}{|l|}{ Facility volume* } \\
\hline Bottom two quintiles ${ }^{a}$ & 1.00 & & \\
\hline 3rd quintileb & 1.08 & $0.68-1.70$ & 0.750 \\
\hline 4th quintile ${ }^{c}$ & 1.21 & $0.85-1.73$ & 0.299 \\
\hline 5 th quintile ${ }^{\mathrm{d}}$ & 1.76 & $1.22-2.54$ & 0.003 \\
\hline
\end{tabular}

RT, Radiation therapy. $*$ Patients per year: ${ }^{\mathrm{a}}<1, \mathrm{~b} 1-1.25,{ }^{\mathrm{c}} 1.25-2,{ }^{\mathrm{d}}>2$.

CTCL for which doses of $\geq 30$ Gy was recommended was subcutaneous panniculitis-like T-cell lymphoma ( $\geq 40 \mathrm{~Gy}$ ), a rare entity that likely represented only a small percentage of the patients in our study (26).

Our own analysis of the NCDB data showed increasing use of low-dose RT regimens for patients with CTCL. We 
also identified several factors associated with the adoption of low-dose RT, including high facility volume and more recent treatment. However, most patients receiving RT for CTCL are treated with doses $\geq 30$ Gy. Collectively, these findings suggest that low-dose RT for CTCL is being adopted slowly, and its adoption is driven in part by institutional experience. Considering the recent literature on low-dose TSEBT and local RT, our findings also suggest that many patients may be receiving doses higher than necessary to achieve an effective response with minimal toxicity.

We also found that the proportions of patients with CTCL treated with RT as part of initial therapy are trending downward with more recent diagnosis. Reasons why are unclear, but it is possible that as practitioners gain understanding of the indolent nature of this disease, they tend to defer the use of RT. We found several factors associated with underuse of RT that may reflect healthcare disparities, specifically that Black and Asian patients were much less likely to receive RT than were White and male patients. This finding stands in contrast to a previous study of the Surveillance, Epidemiology, and End Results database showing no racial differences in the administration of RT for patients with mycosis fungoides (18). However, our finding that younger patients and women were also less likely to receive RT was in line with their results. Surprisingly, we also found that patients treated at an academic or research center were less likely to receive upfront RT. This may reflect the availability of other treatments and clinical trials at such centers, as practitioners may hold off RT until other treatment options have failed.

This study did have several inherent limitations. As alluded to earlier, the NCDB records only the initial treatment of patients with CTCL. Because CTCL is an indolent disease with a long natural history, patients who were not treated initially with RT may have gone on to receive RT later. As is the case in any retrospective review, we may not have been able to control for unknown variables that may have been unbalanced between the study groups. In addition, exactly which adjuvant therapies were given to the patients in this study is unknown, as variables used to code chemotherapy or other forms of treatment are broad and can encompass any number of other therapeutic agents. Notably, the NCDB does not code specifically for TSEBT or localized RT, so the combined trends for both treatment modalities are reported here.

In conclusion, although RT doses for patients with CTCL have been trending downwards since past reports of adequate response rates and lower toxicity with RT doses of $<30 \mathrm{~Gy}$, most patients with CTCL are still receiving RT doses of $30 \mathrm{~Gy}$ or more. This pattern seems to be driven, in part, by institutional experience, as higher-volume facilities are more likely to offer low-dose RT for CTCL. Overall, RT has been used less often for the upfront treatment of CTCL in more recent years, and factors associated with the underutilization of RT include Black or Asian race, female gender, and treatment at an academic or research center.

\section{Acknowledgements}

No funding or sponsorship was received for this study or publication of this article.

\section{References}

1 Bilimoria KY, Stewart AK, Winchester DP and Ko CY: The National Cancer Data Base: a powerful initiative to improve cancer care in the United States. Ann Surg Oncol 15: 683-690, 2008.

2 Chowdhary M, Chhabra AM, Kharod S and Marwaha G: Total Skin Electron Beam Therapy in the Treatment of Mycosis Fungoides: A Review of Conventional and Low-Dose Regimens. Clinical lymphoma, myeloma \& leukemia 16: 662-671, 2016.

3 Deeths MJ, Chapman JT, Dellavalle RP, Zeng C and Aeling JL: Treatment of patch and plaque stage mycosis fungoides with imiquimod 5\% cream. J Am Acad Dermatol 52: 275-280, 2005.

4 Duvic M, Martin AG, Kim Y, Olsen E, Wood GS, Crowley CA and Yocum RC: Phase 2 and 3 clinical trial of oral bexarotene (Targretin capsules) for the treatment of refractory or persistent early-stage cutaneous T-cell lymphoma. Arch Dermatol 137: 581-593, 2001.

5 Duvic M, Talpur R, Ni X, Zhang C, Hazarika P, Kelly C, Chiao JH, Reilly JF, Ricker JL, Richon VM and Frankel SR: Phase 2 trial of oral vorinostat (suberoylanilide hydroxamic acid, SAHA) for refractory cutaneous T-cell lymphoma (CTCL). Blood 109: 31-39, 2007.

6 Elsayad K, Kriz J, Moustakis C, Scobioala S, Reinartz G, Haverkamp U, Willich N, Weishaupt C, Stadler R, Sunderkotter $\mathrm{C}$ and Eich HT: Total Skin Electron Beam for Primary Cutaneous T-cell Lymphoma. International journal of radiation oncology, biology, physics 93: 1077-1086, 2015.

7 Gathers RC, Scherschun L, Malick F, Fivenson DP and Lim HW: Narrowband UVB phototherapy for early-stage mycosis fungoides. J Am Acad Dermatol 47: 191-197, 2002.

8 Harrison C, Young J, Navi D, Riaz N, Lingala B, Kim Y and Hoppe R: Revisiting low-dose total skin electron beam therapy in mycosis fungoides. International journal of radiation oncology, biology, physics 81: e651-657, 2011.

9 Heald P, Mehlmauer M, Martin AG, Crowley CA, Yocum RC and Reich SD: Topical bexarotene therapy for patients with refractory or persistent early-stage cutaneous T-cell lymphoma: results of the phase III clinical trial. J Am Acad Dermatol 49: 801-815, 2003.

10 Hoppe RT, Harrison C, Tavallaee M, Bashey S, Sundram U, Li S, Million L, Dabaja B, Gangar P, Duvic M and Kim YH: Lowdose total skin electron beam therapy as an effective modality to reduce disease burden in patients with mycosis fungoides: Results of a pooled analysis from 3 phase-II clinical trials. Journal of the American Academy of Dermatology 72: 286-292, 2015.

11 Horwitz SM: NCCN Guidelines Version 3.2018 Mycosis Fungoides/Sezary Syndrome. 2018.

12 Jawed SI, Myskowski PL, Horwitz S, Moskowitz A and Querfeld C: Primary cutaneous T-cell lymphoma (mycosis fungoides and Sezary syndrome): part II. Prognosis, management, and future directions. J Am Acad Dermatol 70: 223.e221-217; quiz 240-222, 2014. 
13 Jones GW, Rosenthal D and Wilson LD: Total skin electron radiation for patients with erythrodermic cutaneous T-cell lymphoma (mycosis fungoides and the Sezary syndrome). Cancer 85: 1985-1995, 1999.

14 Kamstrup MR, Gniadecki R, Iversen L, Skov L, Petersen PM, Loft A and Specht L: Low-dose (10-Gy) total skin electron beam therapy for cutaneous T-cell lymphoma: an open clinical study and pooled data analysis. International journal of radiation oncology, biology, physics 92: 138-143, 2015

15 Kim YH, Martinez G, Varghese A and Hoppe RT: Topical nitrogen mustard in the management of mycosis fungoides: update of the Stanford experience. Arch Dermatol 139: 165-173, 2003.

16 Kim YH, Tavallaee M, Sundram U, Salva KA, Wood GS, Li S, Rozati S, Nagpal S, Krathen M, Reddy S, Hoppe RT, Nguyen-Lin A, Weng WK, Armstrong R, Pulitzer M, Advani RH and Horwitz SM: Phase II investigator-initiated study of brentuximab vedotin in mycosis fungoides and sezary syndrome with variable CD30 expression level: a multi-institution collaborative project. J Clin Oncol 33: 3750-3758, 2015.

17 Morris S, Scarisbrick J, Frew J, Irwin C, Grieve R, Humber C, Kuciejewska A, Bayne S, Weatherhead S, Child F, Wain M and Whittaker S: The Results of Low-Dose Total Skin Electron Beam Radiation Therapy (TSEB) in Patients With Mycosis Fungoides From the UK Cutaneous Lymphoma Group. Int J Radiat Oncol Biol Phys 99: 627-633, 2017.

18 Nath SK, Yu JB and Wilson LD: Poorer prognosis of AfricanAmerican patients with mycosis fungoides: an analysis of the SEER dataset, 1988 to 2008 . Clinical lymphoma, myeloma \& leukemia 14: 419-423, 2014.

19 Navi D, Riaz N, Levin YS, Sullivan NC, Kim YH and Hoppe RT: The Stanford University experience with conventional-dose, total skin electron-beam therapy in the treatment of generalized patch or plaque (T2) and tumor (T3) mycosis fungoides. Arch Dermatol 147: 561-567, 2011.

20 Neelis KJ, Schimmel EC, Vermeer MH, Senff NJ, Willemze R and Noordijk EM: Low-dose palliative radiotherapy for cutaneous B- and T-cell lymphomas. Int J Radiat Oncol Biol Phys 74: 154-158, 2009.

21 Parida DK, Verma KK, Chander S, Joshi RC and Rath GK: Total skin electron irradiation therapy in mycosis fungoides using high-dose rate mode: a preliminary experience. Int J Dermatol 44: 828-830, 2005.

22 Piccinno R, Caccialanza M, Cuka E and Recalcati S: Localized conventional radiotherapy in the treatment of Mycosis Fungoides: our experience in 100 patients. J Eur Acad Dermatol Venereol 28: 1040-1044, 2014.

23 Querfeld C, Rosen ST, Kuzel TM, Kirby KA, Roenigk HH Jr., Prinz BM and Guitart J: Long-term follow-up of patients with early-stage cutaneous T-cell lymphoma who achieved complete remission with psoralen plus UV-A monotherapy. Arch Dermatol 141: 305-311, 2005.
24 Quiros PA, Jones GW, Kacinski BM, Braverman IM, Heald PW, Edelson RL and Wilson LD: Total skin electron beam therapy followed by adjuvant psoralen/ultraviolet-A light in the management of patients with $\mathrm{T} 1$ and $\mathrm{T} 2$ cutaneous $\mathrm{T}$-cell lymphoma (mycosis fungoides). International journal of radiation oncology, biology, physics 38: 1027-1035, 1997.

25 Rosen ST and Querfeld C: Primary cutaneous T-cell lymphomas. Hematology Am Soc Hematol Educ Program: 323-330, 513, 2006.

26 Specht L, Dabaja B, Illidge T, Wilson LD and Hoppe RT: Modern radiation therapy for primary cutaneous lymphomas: field and dose guidelines from the International Lymphoma Radiation Oncology Group. International journal of radiation oncology, biology, physics 92: 32-39, 2015

27 Specht L, Dabaja B, Illidge T, Wilson LD, Hoppe RT and International Lymphoma Radiation Oncology G: Modern radiation therapy for primary cutaneous lymphomas: field and dose guidelines from the International Lymphoma Radiation Oncology Group. International journal of radiation oncology, biology, physics 92: 32-39, 2015.

28 Tandberg DJ, Craciunescu O and Kelsey CR: Radiation Therapy for Cutaneous T-Cell Lymphomas. Dermatol Clin 33: 703-713, 2015.

29 Thomas TO, Agrawal P, Guitart J, Rosen ST, Rademaker AW, Querfeld C, Hayes JP, Kuzel TM and Mittal BB: Outcome of patients treated with a single-fraction dose of palliative radiation for cutaneous T-cell lymphoma. Int J Radiat Oncol Biol Phys 85 : 747-753, 2013

30 Willemze R, Jaffe ES, Burg G, Cerroni L, Berti E, Swerdlow SH, Ralfkiaer E, Chimenti S, Diaz-Perez JL, Duncan LM, Grange F, Harris NL, Kempf W, Kerl H, Kurrer M, Knobler R, Pimpinelli N, Sander C, Santucci M, Sterry W, Vermeer MH, Wechsler J, Whittaker S and Meijer CJ: WHO-EORTC classification for cutaneous lymphomas. Blood 105: 3768-3785, 2005

31 Zackheim HS: Treatment of patch-stage mycosis fungoides with topical corticosteroids. Dermatol Ther 16: 283-287, 2003.

32 Zackheim HS, Kashani-Sabet $M$ and Hwang ST: Low-dose methotrexate to treat erythrodermic cutaneous T-cell lymphoma: results in twenty-nine patients. J Am Acad Dermatol 34: 626$631,1996$.
Received November 2, 2018

Revised November 21, 2018

Accepted November 23, 2018 